\title{
NEGRAFICKÁ DATA A JEJICH STRUKUTRA PRO VYUŽITÍ LCA V BIM
}

\section{NON-GRAPHICAL DATA STRUCTURE FOR THE USE OF LCA IN BIM}

\author{
Ing. Michal Brandtner ${ }^{1 *}$ \\ ${ }^{1}$ Vysoké učení technické v Brně, Fakulta stavební, Veveři 331/95, 60200 Brno, Česká republika \\ *korespondenční autor: 159111@vutbr.cz
}

\section{REŠERŠNí Př́́SPĚVEK}

REVIIEW ARTICLE

\section{ABSTRAKT CZ}

Článek se zabývá datovou strukturou pro účely posuzování životního cyklu staveb s využitím informačního modelu budovy (BIM). Posuzování životního cyklu (LCA) je metoda, využitelná pro prokázání vhodnosti navržených materiálů, konstrukcí nebo celých budov z hlediska životního cyklu a jeho působení na životní prostředí. Pro samotné hodnocení LCA je stěžejní obstarat vstupní data pro tzv. inventuru životního cyklu (LCI). Cílem článku je definovat, jakou datovou strukturu je nutné získat z BIM modelu pro účely LCI. Nová metodika je postavena na základě informací z datové struktury standardizace negrafických informací modelu, zvané SNIM. Výhody představené metodiky byly prokázány na př́ípadové studii. Tyto výsledky jsou vhodné, pro rozšíření BIM modelu o nová data, nezbytná pro výpočty LCA.

Klíčová slova: Stavebnictví; metoda LCA; BIM model; LCI; SNIM

\section{ABSTRACT}

The article deals with the data structure for the purpose of Life Cycle Assessment (LCA) of buildings using the Building Information Model (BIM). LCA is a method that can be used to demonstrate the suitability of proposed materials, structures, or buildings in terms of their whole life cycle and its environmental impact. For the LCA evaluation it is crucial to obtain life cycle inventory (LCI) input data. The aim of the article is to define a BIM data structure for LCI purposes. The new methodology is based on standardization of non-graphic information model data structure called SNIM. Advantages of the proposed methodology have been demonstrated on the case study. These results are useful for expanding the BIM model with new data necessary for further LCA calculations.

Key words: Construction industry, the LCA methodology, the BIM model, life cycle inventory (LCI), SNIM

\section{1 ÚVOD}

Stavebnictví je z hlediska produkce či vytváření pracovních míst strategicky důležité odvětví pro hospodářství České republiky. Jde nicméně o jedno z nejméně digitalizovaných odvětví. Je tedy zřejmý celospolečenský požadavek pro digitalizaci stavebnictví. Jedním z prostředků pro digitalizaci stavebnictví je zavedení metody BIM (Building Information Model / Management). Mnohem vyšší http://doi.org/10.51704/cjce.2021.vol7.iss01.pp16-26 
efektivita při využívání metody BIM je předpokládána v rámci zavedení koncepce digitalizace celého stavebnictví (Stavebnictví 4.0) pro Českou republiku. BIM, při vhodném užití, může být jedním z efektivních nástrojů pro naplnění principů udržitelné výstavby v celém životním cyklu stavby. A to nejen ve fázi koncepčního návrhu a při výstavbě, ale i při provozování a dožití stavby. BIM kombinuje využití počítačového parametrického 3D modelování s informacemi o stavbách za účelem zlepšení spolupráce, koordinace a procesu rozhodování při výstavbě ale i během provozu stavby [1].

Problematika posuzování environmentálních aspektů staveb, výrobků a materiálů v nich obsažených je aktuálním tématem v souvislosti s požadavkem na udržitelnou výstavbu dle Směrnice Evropského parlamentu a Evropské komise č. 305/2011 [2]. Nový požadavek na stavební výrobky, ale i na celá stavební díla, spočívá v udržitelném využívání přírodních zdrojů pro zajištění šetrnosti budov k životnímu prostředí. Udržitelné využívání přírodních zdrojů souvisí s možnostmi opětovného využití a recyklace jednou nebo vícekrát použitých materiálů pro výstavbu, ale rovněž s recyklací celých staveb či použití materiálů a surovin šetrných k životnímu prostředí již během nové výstavby. Jedním ze způsobů, jak vyhovět požadavkům a jednoznačně prokázat udržitelnost daného stavebního záměru, je metoda posouzení životního cyklu (LCA). Metodou posouzení životního cyklu stavebních výrobků ale i celých stavebních děl lze významně přispět ke snižování emisí skleníkových plynů, což je jeden z hlavních cílů Pařížské dohody z roku 2017 [3] pro Evropskou Unii a její členské státy, včetně ČR.

\subsection{Metoda LCA}

Metoda LCA je definována jako analytická metoda, založená na hodnocení environmentálních dopadů na životní prostředí výrobků, služeb či technologií [4]. Posuzování životního cyklu je také metoda využitelná pro prokázání vhodnosti navržených materiálů, konstrukcí nebo celých budov z hlediska životního cyklu a jeho působení na životní prostředí. Kočí [4] popisuje přístup metody LCA $\mathrm{k}$ hodnocení environmentálních dopadů na životní prostředí s ohledem na celý životní cyklus produktů, tj. od stádia získávání a výroby prvotních materiálů přes stádium výroby produktů, jejich užívání až po samotné odstranění či opětovné využití produktů v podobě recyklace. Environmentální dopady produktů jsou hodnoceny za základě posouzení vlivu environmentálních aspektů (materiálových a energetických toků), jež sledovaných systém vyměňuje se svým okolím, tedy s životním prostředím. Významným př́nosem metody LCA je vyjadřování environmentálních dopadů pomocí takzvaných kategorií dopadu. Kategorie dopadu je specifických problém životního prostředí, na jehož rozvoji se lidská činnost $\mathrm{v}$ důsledku výměny látek či energií s okolním prostředím podílí. Př́kladem kategorií dopadu může být globální oteplování, úbytek stratosférického ozonu či eutrofizace.

\subsection{Produkt a jeho stádia dopadů na životní prostředí}

Každý produkt během své existence vstupuje do několika stádií majících různé dopady na životní prostředí. Autor Kočí ve své publikaci popisuje životní cyklus produkti̊, který má různé dopady na životní prostředí, ve čtyřech hlavních stádiích. První stádium získávání surovin pro výrobu potřebných materiálů pro výrobu produktu zahrnuje těžbu ropy, železný rud či dřeva a jejich dopravu z místa, kde jsou získávány, do místa dalšího zpracování. Druhé stádium popisuje výrobu produktu z již získaných materiálů a surovin v prvním stádiu. Stádium zahrnuje přeměňování získaných surovin na materiály, které jsou použitelné v další průmyslové výrobě. Přeměňování surovin zahrnuje například také spotřebu elektrické energie či různých paliv. Třetí stádium uživání produktu zahrnuje spotřebu produktu či jeho využití pro funkci, ke které byl vyroben. Nedílnou součástí tohoto stádia jsou opět energetické a surovinové požadavky, které budou sloužit pro samotný provoz produktu a jeho př́ípadné 
opravy, uskladnění či údržbu. Čtvrté, poslední stádium, popisuje již závěrečné odstranění produktu včetně energetických a materiálových nároků na odstranění produktu či př́ípadně na jeho recyklaci [4].

\subsection{Posuzování životního cyklu pomocí kategorií dopadu}

Životní cyklus produktů a hodnocení jejich dopadu na životní prostředí pomocí tzv. kategorií dopadu Kočí dále dělí na šest konkrétních oblastí: (i) Globální oteplování a klimatické změny, (ii) Úbytek stratosférického ozonu, (iii) Acidifikaci, (iv) Eutrofizaci, (v) Vznik fotooxidantů a (vi) Úbytek surovin. Každá z těchto kategorií dopadu zahrnuje procesy a důsledky, jakými je negativně ovlivňováno životní prostředí. Globální oteplování zahrnuje zvyšování průměrné teploty atmosféry vlivem zachycování většího množství energie $\mathrm{v}$ atmosféře, které vede ke klimatickým změnám na globální úrovni či k tzv. skleníkovému jevu. Úbytek stratosférického ozonu vede k pronikání většího množství UV záření na zemský povrch, což vede k nepříznivému ovlivnění zdraví člověka či kvality životního prostředí. Acidifikace je proces okyselování půdního nebo vodního prostředí způsobený vypouštění kyselinotvorných látek do atmosféry, vody a půdy. Okyselené srážky kondenzují na pevných površích či se rozpouštějí ve vodě, což vede k okyselování půdy, vody a stavebních materiálů. Zmíněné látky jsou škodlivé také pro rostliny a stromy. Eutrofizace souvisí s obohacováním prostředí živinami, což vede k zarůstání povrchových vod, k nedostatku kyslíku ve vodách či ke zhoršení kvality zdrojů pitné vody. Vznik fotooxidantů zahrnuje nepríiznivé působení ozonu či jiných látek v prŕzemní vrstvě atmosféry, což vede knegativními vlivu na životní prostředí v podobě vzniku různých nemocí a ovlivňování zdraví živých organismů. Úbytek surovin je spojen s nadměrnou těžbou neobnovitelných zdrojů člověkem, což vede k narušování ekosystémů a k ovlivnění množství surovin dostupných v budoucnosti [4]Chyba! Nenalezen zdroj odkazů.

Všechny procesy a operace podílející se na jednotlivých fázích životního cyklu produktů tvoří jeden celek nazývaný produktový systém. Produktový systém sestává z procesů a toků. Procesy jsou jednotlivé operace přeměňující vstupy na výstupy. Toky představující spojnice procesů. Typickou jednotkou materiálových toků je hmotnost v kg, objem, plocha, počet kusů nebo čas. Energetické toky jsou vyjádřeny $\mathrm{v} \mathrm{MJ}$, respektive $\mathrm{v} \mathrm{kWh}$.

\subsection{Procesní rámec LCA}

Postup sestavování studií LCA je normativně upraven v ČSN EN ISO 14040 [5] a v ČSN EN ISO 14044 [6]. Studie LCA sestává ze čtyř základních fází [5]:

\section{1) Fáze stanovení cíle a rozsahu}

V první fázi LCA musí být jasně popsáno, co je předmětem posuzování, k čemu má studie sloužit, komu bude určena a jaká opatření budou přijata na základě jejích závěrů. V této fázi se definují základní parametry plánovaného posouzení. Stanoví se hloubka a rozsah posouzení - tzv. hranice systému. Jedná se o soubor kritérií specifikujících jednotlivé procesy částí produktového systému. Např. Cradle-to-Gate (od kolébky k bráně), Cradle-to-Cradle (od kolébky ke kolébce), Gate-to-Gate (od brány k bráně). Dále se zvolí funkční jednotky a referenční toky (např. $1 \mathrm{~m}^{3}$ betonu C20/25) a vybere se nejvhodnější metoda shromažd’ování a vyhodnocování dat (např. př́imé měření, numerické modelování, výpočet, získání dat z existujících databází). Následně se zvolí posuzované kategorie dopadu odpovídající metodice a cílům posouzení (např. (i) Globální oteplování a klimatické změny, (ii) Úbytek stratosférického ozonu, (iii) Acidifikace, (iv) Eutrofizace, (v) Vznik fotooxidantů a (vi) Úbytek surovin.). Definice rozsahu zahrnuje také např. alokační postupy, požadavky na údaje, předpoklady, omezení apod. [5]. 


\section{1) Fáze inventarizační analýzy (LCI)}

Jedná se o fázi, ve které zjišstujeme, co všechno zahrnuje posuzovaný produktový systém. Fáze inventarizační analýzy (Life Cycle Inventory) slouží ke zjištění a vyčíslení množství všech materiálových a energetických toků vstupujících a vystupujících do a z produktového systému. Součástí inventarizace je sběr údajů a dat, výpočet údajů a alokace úniků, týkajících se energetické a materiálové náročnosti všechny zúčastněných procesů. Výstupem inventarizační analýzy je sada hodnot shrnující materiálové a energetické toky překračující hranice produktového systému. Tuto sadu dat označujeme jako inventarizační profil či ekovektor [4]. Sesbírané údaje pro každý jednotkový proces uvnitř hranic systémů mohou být roztříděny na kategorie: energetických vstupů, vstupů surovin, vstupů pomocných materiálů, produktů, koproduktů a odpadu, emisí do ovzduší, vypouštění do vody a půdy a ostatní environmentální aspekty. Výpočet údajů zahrnuje ověření správnosti shromážděných údajů, přiřazování údajů $\mathrm{k}$ jednotkovým procesům a přiřazování údajů $\mathrm{k}$ referenčnímu toku funkční jednotky ve snaze vytvořit výsledky inventarizace definovaného systému pro každý jednotkový proces a definované funkční jednotky produktového systému, který má být modelován [5].

\section{2) Fáze posuzování dopadů}

Následuje fáze, ve které je zjištěno, co produktový systém způsobuje. Dochází ke zpracování údajů získaných inventarizační analýzou - hodnocení dopadů životního cyklu a vyhodnocují se dopady produktového systému na dané kategorie dopadu. Dochází k vyhodnocení dopadů produktového systému v určité kategorii dopadu pomocí tzv. charakterizačního modelu. Existuje velké množství různých charakterizačních modelů. Součástí fáze posuzování dopadů je normalizace výsledků nebo způsob interpretace výsledků charakterizace a vážení výsledků, které v určitých př́ípadech vyzdvihuje vliv určité kategorie dopadu nad ostatní výsledky [5].

\section{3) Fáze interpretace}

Interpretace je fáze LCA, ve které jsou společně zjišstována zjištění z inventarizační analýzy a posuzování dopadu a je považována za nejdůležitější fázi každé studie LCA. Interpretační fáze by měla dodat výsledky, kterou jsou v souladu s předem definovaným cílem a rozsahem. Před prezentováním zjištěných výsledků cílové skupině je nutné provést jejich nezávislou analýzu a kontrolu $\mathrm{v}$ podobě kritického přezkoumání nezávislými odborníky. V rámci této fáze by měly proběhnout kontroly úplnosti, konzistence, analýzy nejistot, citlivosti a obměny a hodnocení kvality vstupních údajů. Součástí interpretace je sepsání závěrečné zprávy obsahující kromě popisu řešení a zjištěných výsledků i popis všech přijatých zjednodušení, odhadů či předpokladů [5].

\section{POPIS SOUČASNÉHO STAVU ŘEŠENÉ PROBLEMATIKY}

Při provádění studií LCA ve stavebnictví je nutno shromáždit určité množství dat o budově. K tomuto účelu je možné za určitých podmínek využít informační model budovy, který obsahuje, kromě geometrické části, rovněž informační část.

V roce 1990 se poprvé objevuje komplexní environmentální analýza zátěží, modely plnohodnotného hodnocení životního cyklu a s nimi spojená kalkulace životního cyklu. Začátkem 21. století byl vytvořen program Life Cycle Initiative, jehož cílem bylo praktikovat myšlenky životního cyklu do praxe [7].

Propojením metody LCA s možností využití datové struktury BIM modelu se již zabývalo mnoho autorů. Antón [8] v závěru článku představila dva př́stupy integrace mezi LCA a BIM. Jeden z nich je posouzení celého životního cyklu konstrukce a druhý př́stup je materiálově orientovaný. 
Autoři dalšího článku [9] přichází s metodou automatických výpočtů LCA v rané fázi, tedy již na první úrovni podrobnosti BIM (LOD100). To by mělo vést $\mathrm{k}$ lehčím úpravám výpočtů během dalšího vývoje BIM modelu. K tomu, aby bylo možné tohoto cíle dosáhnout, je potřeba nových vrstev dat a jejich formátů. Tato nová datová vrstva by měla vyplnit informační mezery mezi extrahovanými daty BIM a stávajícími daty LCA, poskytovanými běžnými databázemi. Výsledkem tohoto článku je přiblížení této metody a dalším doporučeným krokem je testování této metody v budoucích vědeckých pracích.

Efektivita analýzy životního cyklu je řešena v dalším článku [10]. Autoři tohoto článku se zabývají propojením mezi nástrojem založeným na př́stupu BIM a nástrojem LCA za využití software Gabi 6. V článku bylo prokázáno, že BIM plug-in modul může poskytnout potřebná data pro každou fázi návrhu. To znamená, že projektant má možnost provést plnou analýzu životního cyklu mnohem efektivněji.

Další článek [11] zabývající se hodnocením životního cyklu (LCA) a nákladů životního cyklu (LCC) pomocí metody BIM představuje kritické zhodnocení a přezkoumání vhodných způsobů integrace LCA a LCC pomocí BIM na základě již dosud prezentovaných recenzovaných článků. Článek představuje možnost vývoje čtyřstupňového metodického rámce pro hodnocení LCA a LCC pomocí BIM. Metodický rámec zahrnuje: 1) Definování systémové hranice LCA a LCC, 2) Definování základních parametrů a analýzy zdrojů, 3) Výpočet dopadů na životní prostředí a výsledných nákladů a 4) Analýza a optimalizace výsledků. Výsledky článku identifikují 3 hlavní přístupy pro možnost hodnocení LCA a LCC s využitím BIM modelu:

1. Využití stávajícího softwaru BIM pro získání množství jednotlivých prvků v modelu a pro zisk dalších údajů,

2. export dat $\mathrm{z}$ BIM modelu na externí platformu,

3. zahrnutí získaných informací do stávajícího BIM modelu.

Článek, publikován Holbergem a kol. [12], se zaměřuje na digitální nástroje založené na informačním modelování stavby (BIM) s potenciálem pro usnadnění hodnocení dopadu výkonnosti budov na životní prostředí. Článek poukazuje na to, že v mnoha Evropských zemích jsou k dispozici databáze LCA využitelné jako vstupní data do potřebných nástrojů založených na BIM. Článek také popisuje první aplikaci nástroje BIM-LCA k vyhodnocení vlivu potenciálu globálního oteplování (GWP) v průběhu celého návrhu skutečné budovy. Výsledky ukazují, že zjištěné hodnoty GWP ve fázi návrhu budovy jsou dvakrát vyšší než hodnoty pro konečný objekt. Autoři tyto rozdíly přisuzují především využívání zástupných materiálů (ve fázi návrhu), které jsou zpřesněny až v pozdější fázi projektu. Dle autorů může na tuto skutečnost mít také vliv nadhodnocení GWP v procesu návrhu objektu s využitím BIM modelu, které může být zavádějící až kontraproduktivní. V závěru článku autoři objasňují, že automatický výpočet pomocí dostupných softwarových nástrojů vede ke špatným výsledkům. $Z$ toho důvodu je upozorněno na důležitost analytických postupů pro toto hodnocení, které vypočtené hodnoty co nejvíce přiblíží skutečnému návrhu v praxi. Závěr článku také popisuje 3 obecné důvody tohoto vzniklého problému: 1) Jelikož je postup hodnocení přizpůsoben pro práci s předdefinovanými komponenty, je spíše vhodný pro průmyslově vyráběné stavební objekty. Běžní projektanti či architekti by se mohli díky tomuto přístupu cítit omezeni při navrhování inovativních projektů. 2) Výpočet GWP je přizpůsoben $\mathrm{k}$ použití při zjednodušených přistupech založených na využití povrchové plochy modelu namísto jeho objemu. Tento př́stup se osvědčil v raných fázích návrhu, není však přesný pro certifikaci celého objektu. 3) Softwarové nástroje pro LCA se strojově učí na základě předchozích projektů a automaticky využívají typické předpoklady pro zástupné materiály ve fázi návrhu objektů. Je nutno vytvořit rozsáhlou databázi BIM modelů stávajících staveb s požadovanými informacemi pro LCA, která dosud neexistuje. 
Integrace analýzy LCA a LCC v prostředí založeném na BIM je předmětem dalšího článku, který publikoval Santos a kol. [13]. Článek v rámci studie zkoumá potenciál BIM jako úložiště pro hodnocení životního cyklu (LCA) a nákladů životního cyklu (LCC) a způsob, jakým by tyto informace měly být použity pro environmentální a ekonomickou analýzu. Autoři se zamýšlejí o potenciálu BIM jako úložiště dat a o jeho kapacitě pro podporu automatického a poloautomatického environmentálního a ekonomického hodnocení. V rámci studie byl navržen koncept BIM-LCA a BIM-LCC s využitím formátu IFC pro integraci a výměnu informací v prostředí založeném na BIM. Bylo zjišsěno, že ačkoli nejnovější schémata IFC již uvažují s využitím dat k získání požadovaných informací k provedení komplexních studií LCA, je stále zapotřebí provést ještě značné množství studií LCA a LCC. Práce přispívá k základním znalostem, které jsou nezbytné pro budoucí možnost implementace nástroje pro provedení studií LCA/LCC vývojár̆i softwarů.

Posuzováním životního cyklu budov v souvislosti s využitím BIM, analýzou předchozích př́stupů a shrnutím základních informací o této problematice se věnoval článek autora $\mathrm{M}$. Brandtnera [14]. Tento článek navazuje na shrnuté poznatky a závěry z tohoto př́spěvku.

Problematikou BIM se zabýval také Jarský a kol. [15] v publikaci věnované př́ípravě a realizaci staveb. V publikaci je zmínka o možnosti využití BIM modelu pro demonstraci celého životního cyklu budovy včetně procesu výstavby a provozu staveb. Téma propojení externích dat s BIM modely za předpokladu přidání dalšího datového rozměru $\mathrm{k}$ BIM modelu je popsáno v kapitole věnující se nD BIM modelům.

Na základě výše uvedených referencí lze konstatovat, že autoři se již v minulosti zabývali možnostmi propojení studií LCA s informacemi obsaženými ve 3D modelu, který je součástí prostředí BIM.

Za klíčový považuji článek [11] z roku 2021 týkající se rešerše dosud provedeného výzkumu v rámci řešené problematiky. Výsledky článku identifikují 3 hlavní př́ístupy pro možnost hodnocení LCA a LCC s využitím BIM modelu:

1. Využití stávajícího softwaru BIM pro získání množství jednotlivých prvků v modelu a pro zisk dalších údajů,

2. export dat z BIM modelu na externí platformu,

3. zahrnutí získaných informací do stávajícího BIM modelu.

\section{METODIKA}

Pro posouzení životního cyklu produktů s možností hodnocení jejich dopadu na životní prostředí metodou LCA je potřeba stanovit hodnoty jednotlivých indikátorů kategorií dopadu s ohledem na jednotlivá stádia životního cyklu produktů. Tyto hodnoty, tvořící soubor výsledků, musí mít kromě konkrétních hodnot, také jednoznačně definovány jednotky. Jednotlivé soubory výsledků jsou poté přiřazeny do konkrétních druhů kategorií dopadu, které mají různé vlivy na životní prostředí. V grafické a informační části BIM modelu stavebního díla jsou jednoznačně definovány parametry, které je možno využít pro hodnocení LCA. V souvislosti se standardizací negrafických informací modelu a se vznikem již zmíněných standardů a parametrů se nabízí možnost doplnění BIM modelu o konkrétní informace ze SNIM pro komplexní posouzení stavebního díla z hlediska jeho celého životního cyklu (LCA).

Standardizace negrafických informací 3D modelu neboli zkráceně SNIM je soubor informací a standardů, které byly vyvinuty zejména pro projektování s využitím BIM modelu v prostředí České republiky. K jednotlivým prvkům 3D modelu byly přiřazeny parametry (negrafické informace), které jsou dále rozděleny dle požadavků pro jednotlivé stupně projektové dokumentaci v souvislosti s danou fází výstavby. SNIM obsahuje seznam parametrů, které jsou přiřazeny ke konkrétním konstrukcím 
a trrídník stavebních konstrukcí, který jednotlivé typy konstrukcí rozděluje dle technických a parametrických informací. Tř́́dník stavebních konstrukcí byl vytvořen z důvodu snahy o lepší orientaci v projektu za pomocí databázového vyhledávání.

Metoda výběru dat z prostředí SNIM je popsána ve fázi studie výstavby. Z databáze SNIM budou převzaty objemy jednotlivých konstrukcí a takzvaná data "syntaxe značení" obsahující značení konstrukcí. Data "syntaxe značení" ze SNIM budou použita pro účely základní strukturu LCI (studie LCA). Nejsou v těchto datech obsaženy indikátory kategorií dopadu (emise). Proto se musí přiřadit z externích zdrojů (databáze / individuálně zjištěná data od výrobců / producentů materiálu / výrobků). Př́klad vzhledu datové struktury pro jednu kategorii materiálu je uveden v tabulce 1 .

\begin{tabular}{|c|c|c|c|c|c|}
\hline & $\begin{array}{c}\text { Značení dle } \\
\text { SNIM }\end{array}$ & Podkategorie & Popis & MIN & MAX \\
\hline Typ konstrukce & XX000 & Specifikace konstrukce & $\cdots$ & 000 & 000 \\
\hline
\end{tabular}

Tab. 1 Př́́klad vzhledu datové struktury pro jednu kategorii materiálu

V rámci hodnocení byly uvažovány emise následujících látek: $\mathrm{CO} 2, \mathrm{SO} 2, \mathrm{NOX}, \mathrm{CO}, \mathrm{CH} 4, \mathrm{~N} 2 \mathrm{O}, \mathrm{HCl}$ a HF. Množství těchto emisí bylo uvažováno v pěti kategorií dopadu pro oblast České republiky. Jedná se o potenciál globálního oteplování (GWP), acidifikační potenciál (AP), eutrofizační potenciál (EP), úbytek stratosférického ozónu (ODP) a potenciál vzniku fotooxidantů (POCP). Indikátory kategorií dopadu byly převzaty ze softwaru Gabi [13] z externí databáze EPD, která zahrnuje 3 kategorie: A1 - raw material supply, A2 - transport, A3 - core processes. Převzaty byly indikátory kategorií dopadu pro typy betonů obsažené v referenčním objektu dle třídy, pevnosti a stupně vlivu prostředí.

Pro klasifikaci těchto dat bylo využito maticového řešitele MATLAB. Vstupní data pro řešení jsou dvě tabulky. Jedná se o tabulku syntaxí značení a tabulku indikátorů dopadu. První je tabulka prvků, která obsahuje název prvku, jeho objem, pevnost a stupeň vlivu prostředí. Druhá tabulka obsahuje hodnoty indikátorů kategorií dopadu (LCI) pro každý typ betonu a stupeň vlivu prostředí. Indikátory kategorií dopadu jsou CO, Nox, Sox, CH4, CO3, N20, $\mathrm{HCl}$ a HC.

Nejdřive je načten první řádek prvků, ze kterého se vezme objem prvku, pevnost beton a stupeň vlivu prostředí. Na základě pevnost betonu a stupně vlivu prostředí je z druhé tabulky přiřazena konkrétní hodnota LCI. Obecně MATLAB přiřadí hodnotu LCI pro každý stupeň vlivu prostředí, ale pro tento konkrétní prríklad je uvažováno pro všechny prvky pouze se stupněm vlivu prostředí XC1. Přiřazená hodnota LCI je pouze pro objem $1 \mathrm{~m} 3$ betonu, proto jsou všechny hodnoty vynásobeny hodnotou objemu daného prvku. Objem každého konkrétního prvku vynásobený př́islušnou hodnotou LCI je vygenerován do nové tabulky, ze které jsou postupně filtrovány další informace. Při zadání hodnoty konkrétního typu (pevnosti) betonu (např. C 20/25) je vygenerována hodnota LCI konkrétního prvku z daného betonu. V dalším kroku jsou všechny hodnoty LCI pevnosti betonu jsou sečteny a výsledné hodnoty jsou přeneseny do grafu. Proces je opakován pro všechny zvolené typy betonu (v prezentovaném př́padě 3 typy) a poté podle jednotlivých hodnot LCI jsou vytvořeny grafy - co jeden prvek LCI, to jeden graf.

\section{PŘ́lPADOVÁ STUDIE}

Př́padová studie je zaměřena na hrubou stavbu reálného objektu ŽB skeletu knihovny ve fázi studie výstavby s daty pro DSP ze SNIM. Jedná se objekt vymodelovaný v Revitu (BIM model), který byl následně převeden do programu Lumion, ve kterém byla vytvořena vizualizace. Pro účely výpočtu byly z BIM modelu převzaty objemy jednotlivých konstrukcí tvořící hrubou stavbu objektu. Jedná se o samostatně stojící stavbu se třemi nadzemními podlažími. Půdorys objektu je ve tvaru čtverce 
s vystupující severní částí. Z hlediska stavebního řešení se jedná o monolitický železobetonový skelet založený na základové desce o mocnosti 800-1200 mm. Stropní konstrukci tvoří trámový strop podepřený příčlemi a desky vyztužené v jednom směru. Stropní konstrukci podpírají monolitické železobetonové sloupy kruhového průřezu z betonu C 20/25 - XC1 o průměru $500 \mathrm{~mm}$ a monolitické ztužující stěny z betonu C 20/25 - XC1 tloušt'ky 250 a 300 mm tvořící ztužující jádra v místech budoucího schodiště a výtahu. Stropní monolitická konstrukce je tvořena deskou o mocnosti $200 \mathrm{~mm}$ vyztuženou $\mathrm{v}$ jednom směru a podepřenou výztužnými trámy o šířce $250 \mathrm{~mm}$, výšce $400 \mathrm{~mm}$ a výztužnou příčlí ve směru druhém širokou $500 \mathrm{~mm}$ o výšce $700 \mathrm{~mm}$. Jedná se tedy o trámový strop podepřený příčlemi $\mathrm{s}$ deskou vyztuženou $\mathrm{v}$ jednom směru. $\mathrm{Z}$ hlediska materiálu je celá stropní konstrukce navržena z betonu C 25/30 - XC1 s betonářskou výztuží B 500B. Př́stup do jednotlivých podlaží objektu je zajištěn pomocí ŽB schodiště z betonu C 30/37 - XC2.
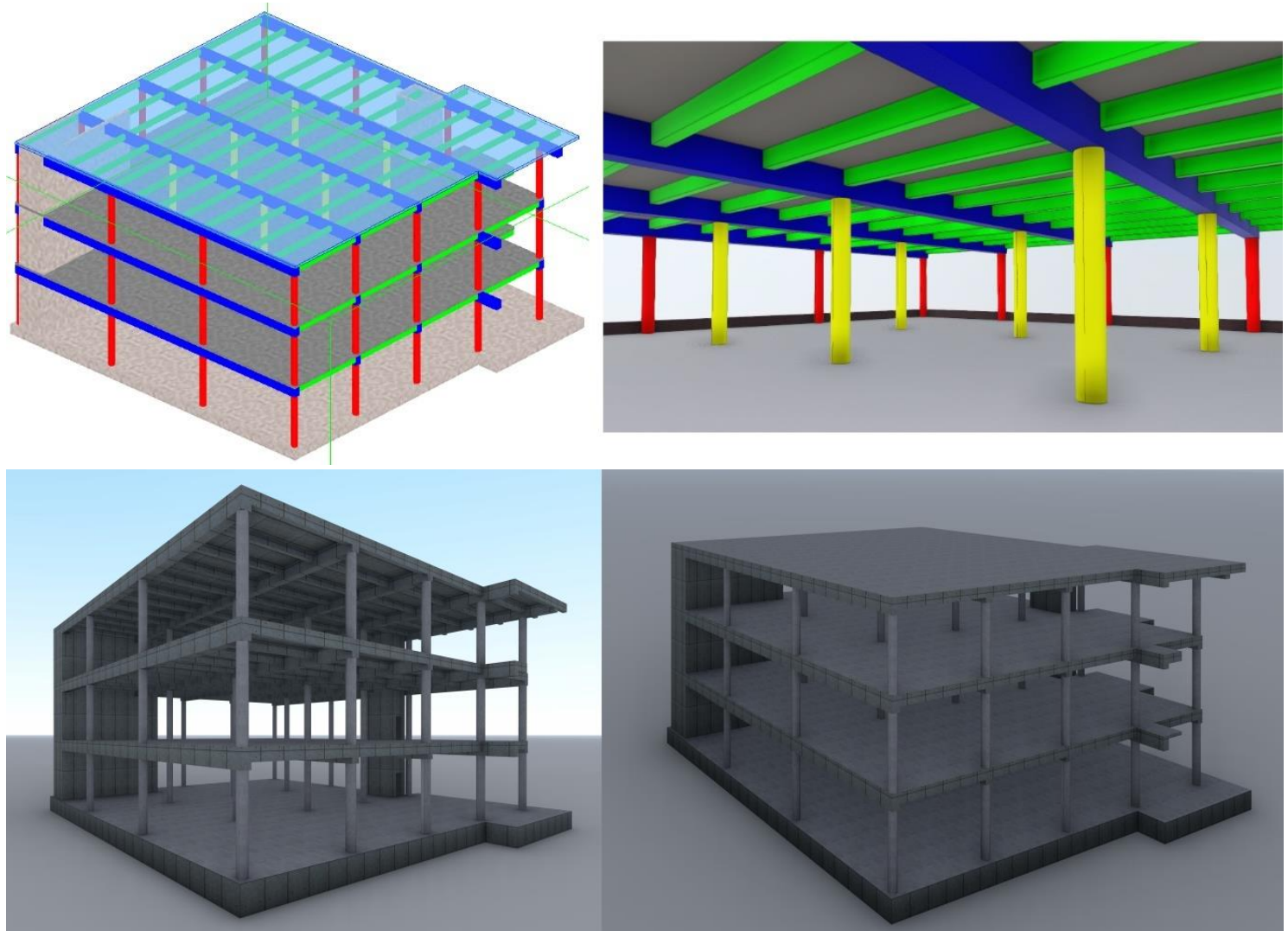

Obr. 1 Referenční objekt: Monolitická železobetonová skeletová konstrukce knihovny [vlastní práce]

\begin{tabular}{|c|c|c|c|c|}
\hline Typ konstrukce & $\begin{array}{c}\text { Celkový } \\
\text { objem }\left(\mathbf{m}^{\mathbf{3}}\right)\end{array}$ & $\begin{array}{c}\text { Objemová } \\
\text { hmotnost }\left(\mathbf{k g} / \mathbf{m}^{\mathbf{3}}\right)\end{array}$ & $\begin{array}{c}\text { Tř́́da a pevnost } \\
\text { betonu }\end{array}$ & $\begin{array}{c}\text { Stupeň vlivu } \\
\text { prostředí }\end{array}$ \\
\hline Základy & 736,54 & 2400 & $\mathrm{C} 30 / 37$ & $\mathrm{XC} 2$ \\
\hline Sloupy & 50,55 & 2300 & $\mathrm{C} 20 / 25$ & $\mathrm{XC} 1$ \\
\hline Stěny & 64,55 & 2300 & $\mathrm{C} 25 / 30$ & $\mathrm{XC} 1$ \\
\hline Průvlaky (př́ǐcle) & 240,71 & 2300 & $\mathrm{C} 20 / 25$ & $\mathrm{XC} 1$ \\
\hline Stropní deska & 468,15 & 2300 & $\mathrm{C} 25 / 30$ & $\mathrm{XC} 1$ \\
\hline Schodiště & 26,52 & 2400 & $\mathrm{C} 30 / 37$ & $\mathrm{XC} 2$ \\
\hline
\end{tabular}

Tab. 2 Data „syntaxe značení“ 


\begin{tabular}{|c|c|c|c|c|c|c|}
\hline $\begin{array}{c}\text { Typ } \\
\text { konstrukce }\end{array}$ & Materiál & $\begin{array}{c}\mathbf{G W P}(\mathbf{k g} \\
\left.\mathbf{C O}_{2} \text { ekv. }\right)\end{array}$ & $\begin{array}{c}\mathbf{A P}(\mathbf{k g} \\
\left.\mathbf{S O}_{2} \text { ekv. }\right)\end{array}$ & $\begin{array}{c}\mathbf{E P}\left(\mathbf{k g ~ P O} \mathbf{4}^{-}\right. \\
\left.\mathbf{3}_{\mathbf{e k v}}\right)\end{array}$ & $\begin{array}{c}\text { ODP }(\mathbf{k g} \\
\mathbf{R 1 1} \text { ekv. })\end{array}$ & $\begin{array}{c}\text { POCP }(\mathbf{k g} \\
\left.\mathbf{C}_{2} \mathbf{H}_{\mathbf{4}} \text { ekv. }\right)\end{array}$ \\
\hline Základy & $\mathrm{C} 30 / 37-\mathrm{XC} 2$ & $1,13 \mathrm{E}-01$ & $1,99 \mathrm{E}-04$ & $3,22 \mathrm{E}-05$ & $2,43 \mathrm{E}-16$ & $8,19 \mathrm{E}-06$ \\
\hline Sloupy & $\mathrm{C} 20 / 25-\mathrm{XC} 1$ & $9,06 \mathrm{E}-02$ & $1,72 \mathrm{E}-04$ & $2,74 \mathrm{E}-05$ & $1,87 \mathrm{E}-16$ & $5,35 \mathrm{E}-06$ \\
\hline Stěny & $\mathrm{C} 25 / 30-\mathrm{XC} 1$ & $1,02 \mathrm{E}-01$ & $1,86 \mathrm{E}-04$ & $2,98 \mathrm{E}-05$ & $2,15 \mathrm{E}-16$ & $6,77 \mathrm{E}-06$ \\
\hline $\begin{array}{c}\text { Průnlaky } \\
\text { (přričle) }\end{array}$ & $\mathrm{C} 20 / 25-\mathrm{XC} 1$ & $9,06 \mathrm{E}-02$ & $1,72 \mathrm{E}-04$ & $2,74 \mathrm{E}-05$ & $1,87 \mathrm{E}-16$ & $5,35 \mathrm{E}-06$ \\
\hline Stropní deska & $\mathrm{C} 25 / 30-\mathrm{XC} 1$ & $1,02 \mathrm{E}-01$ & $1,86 \mathrm{E}-04$ & $2,98 \mathrm{E}-05$ & $2,15 \mathrm{E}-16$ & $6,77 \mathrm{E}-06$ \\
\hline Schodiště & $\mathrm{C} 30 / 37-\mathrm{XC} 2$ & $1,13 \mathrm{E}-01$ & $1,99 \mathrm{E}-04$ & $3,22 \mathrm{E}-05$ & $2,43 \mathrm{E}-16$ & $8,19 \mathrm{E}-06$ \\
\hline
\end{tabular}

Tab. 3 Data ,indikátorů dopadu“

\section{VÝSLEDKY A DISKUZE}

Výsledky výpočtu ukazují procentuální zastoupení kategorií dopadu pro každý typ betonu. Každý závěrečný graf obsahuje součtové hodnoty LCI pro všechny 3 typy betonů. Graf NA Obr. 3 ukazuje procentuální vliv každého betonu o konkrétní pevnosti neboli ukazuje, který beton má největší podíl LCI. Závěr je procentuální rozložení jednotlivých emisních faktorů např́č betonovým zastoupením (materiálovou charakteristikou) ve stavbě. Tyto výsledky jsou vhodné, pro rozšíření BIM modelu o nové data, nezbytné pro výpočty LCA. Model BIM, rozšiřrený o výpočet LCA, povede ke snížení těžby př́rodních zdrojů a také $\mathrm{k}$ pozitivnímu dopadu na životní prostředí.

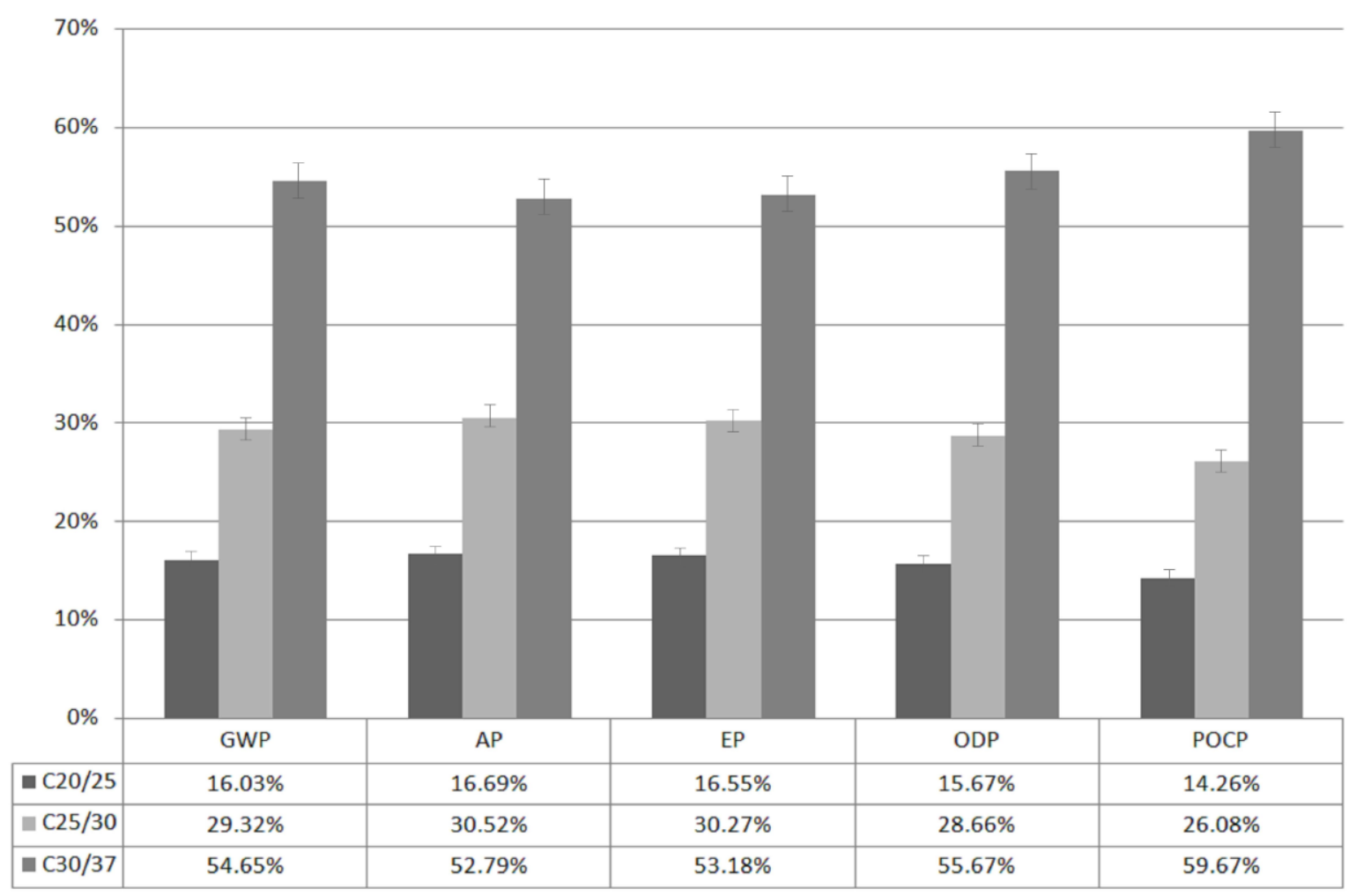

Obr. 2 Graf procentuálního zastoupení LCI pro celý objekt s ohledem na rozložení druhů betonů 

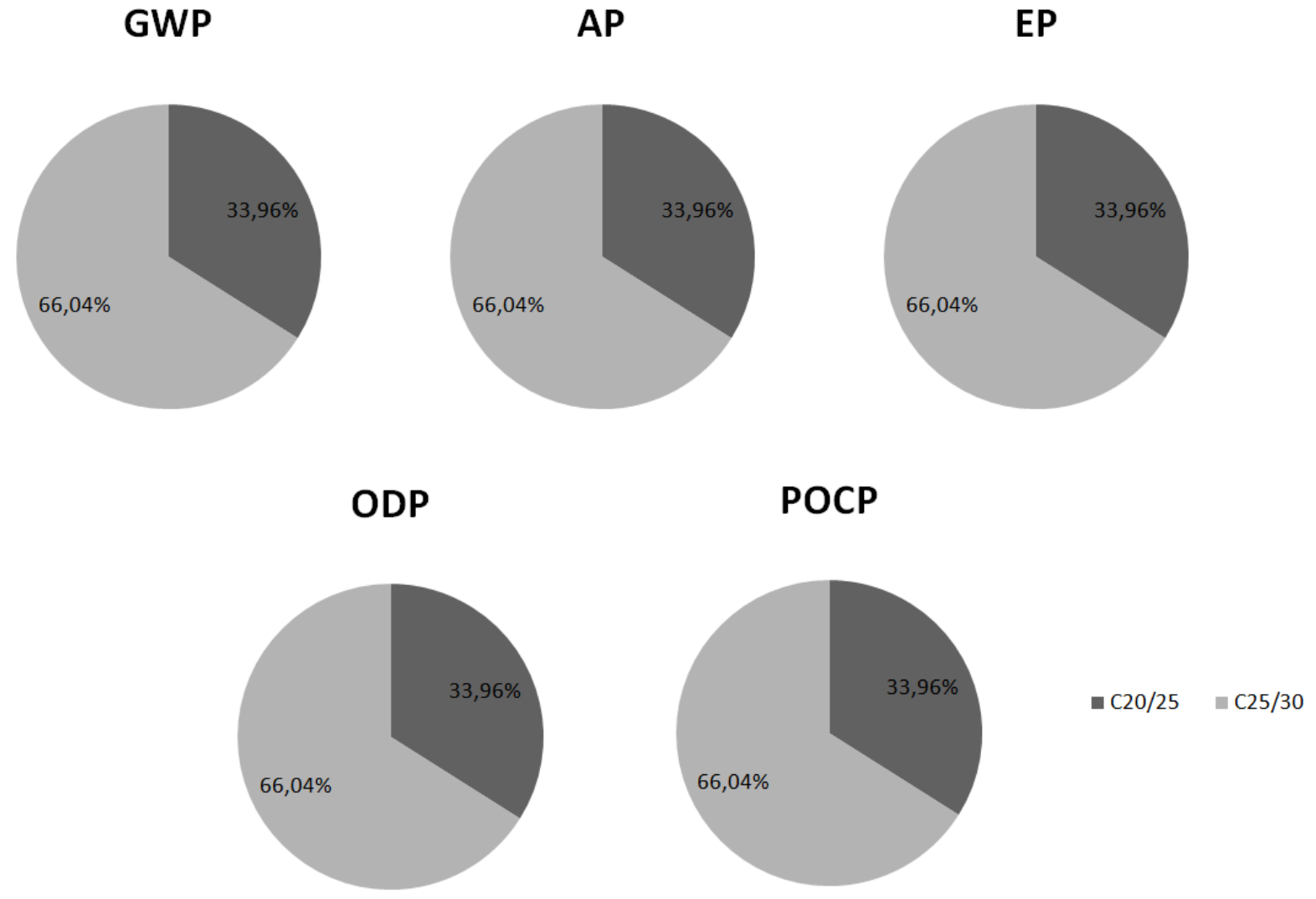

Obr. 3 Graf procentuálního zastoupení LCI, př́íklad pro stupeň vlivu prostředí XC1

\section{ZÁVĚR}

Článek shrnuje teorii, současný stav řešené problematiky a také rámcový postup, jakým je možné v budoucnu prristupovat při výpočtech environmentálních dopadů u konkrétních objektů. Zvolená př́padová studie ověřila navrženou metodiku a ukázala nutnost zpracování mnohem většího počtu př́padových studií konkrétních objektů, jejichž výsledky by mohly být vzájemně porovnány. Zpracování dalších studií, porovnání výsledků těchto studií s již vypočtenými hodnotami a porovnání výsledků s prezentovanými výsledky jiných autorů je doporučeno jako předmět dalšího výzkumu této problematiky. Při ověřování navržené metodiky na konkrétní př́ípadové studii byly zjištěny zejména nedostatky $\mathrm{v}$ oblasti zdrojových dat pro možnost importu hodnot environmentálních dopadů do konkrétních prvků a konstrukcí do BIM modelu řešeného objektu. Bylo by vhodné se do budoucna zabývat rozšířením databáze hodnot LCI zejména pro české prostředí. Ukázalo se také, že ne všechny prvky v objektu lze přiřadit ke konkrétním kategoriím SNIM. Proto by v případě zpracovávání studí pro složitější objekty bylo nutné doplnit některé konkrétní prvky do databáze SNIM. V neposlední řadě by bylo rovněž vhodné vytvořit specializovaný software nebo plug-inu, zabývající se výpočty LCA a propojením studií LCA s BIM modelem pro české prostředí, který bude snadno využitelný ve stavební praxi.

\section{Poděkování}

Článek vznikl za podpory Juniorského specifického výzkumu s registračním číslem FAST-J-21-7288. 


\section{Použitá literatura}

[1] Koncepce zavádění metody BIM v České republice [online]. [cit. 2021-04-17]. Dostupné z: https://www.mpo.cz/assets/cz/stavebnictvi-a-suroviny/bim/2017/10/Koncepce-zavadenimetody-BIM-v-CR.pdf

[2] REGULATION (EU) No 305/2011 OF THE EUROPEAN PARLIAMENT AND OF THE COUNCIL: laying down harmonized conditions for the marketing of construction products and repealing Council Directive 89/106/EEC. In: Strasbourg: European Council, 2011, ročník 2011, $305 / 2011$.
Pařižská
dohoda [online].
[cit.
2021-02-04].
Dostupné
$\mathrm{z}:$ https://www.mzp.cz/cz/parizska_dohoda?fbclid=IwAR15HtLC6BWjTZbHK9o YUBNJp1sCULE3O Iai9a5NewTekiiCvxetMYhc

[4] KOČÍ, Vladimír. LCA a EPD stavebních výrobků: posuzování životního cyklu a environmentální prohlášení o produktu jako cesta k udržitelnému stavebnictví. Praha: Česká rada pro šetrné budovy, 2012. ISBN 978-80-260-3504-6.

[5] ČSN EN ISO 14040: 2006. Environmentální management - Posuzování životního cyklu Zásady a osnova. 2006, $36 \mathrm{~s}$.

[6] ČSN EN ISO 14044: 2006. Environmentální management - Posuzování životního cyklu Požadavky a směrnice. 2006, 68 s.

[7] Jeroen B. Guinée et all. Life Cycle Assessment: Past, Present, and Future. Environ. Sci. Technol., 2011, 45, 90-96. https://doi.org/10.1021/es101316v

[8] ANTÓN, Laura Álvarez a Joaquín DÍAZ. Integration of Life Cycle Assessment in a BIM Environment. Procedia Engineering. 2014, 85, 26-32. ISSN 18777058. https://doi.org/10.1016/j.proeng.2014.10.525

[9] DUPUIS, M., A. APRIL, P. LESAGE a D. FORGUES. Method to Enable LCA Analysis through Each Level of Development of a BIM Model. Procedia Engineering. 2017, 196, 857863. ISSN 18777058. https://doi.org/10.1016/j.proeng.2017.08.017.

[10] BUENO, Cristiane a Márcio Minto FABRICIO. Comparative analysis between a complete LCA study and results from a BIM-LCA plug-in. Automation in Construction. 2018, 90, 188-200. ISSN 09265805. https://doi.org/10.1016/j.autcon.2018.02.028.

[11] LU, Kun, Xiaoyan JIANG, Jingyu YU, Vivian W.Y. TAM a Martin SKITMORE. Integration of life cycle assessment and life cycle cost using building information modeling: A critical review. Journal of Cleaner Production. 2021, 285. ISSN 09596526. https://doi.org/10.1016/j.jclepro.2020.125438

[12] HOLLBERG, Alexander, Gianluca GENOVA a Guillaume HABERT. Evaluation of BIMbased LCA results for building design. Automation in Construction. 2020, 109. ISSN 09265805. https://doi.org/10.1016/j.autcon.2019.102972

[13] SANTOS, Rúben, António Aguiar COSTA, José D. SILVESTRE a Lincy PYL. Integration of LCA and LCC analysis within a BIM-based environment. Automation in Construction. 2019, 103, 127-149. ISSN 09265805. https://doi.org/10.1016/j.autcon.2019.02.011

[14] BRANDTNER, M. Posuzování životního cyklu budov založené na BIM - rešerše. Juniorstav 2020, 22. odborná konference doktorského studia, sborník př́spěvků. Brno: ECON publishing, 2020, (1), 5. ISSN 978-80-86433-73-8.

[15] JARSKÝ, Čeněk. Technologie staveb II. Druhé přepracované a doplněné vydání. Brno: Akademické nakladatelství CERM, 2019. ISBN ISBN978-80-7204-994-3. 